\title{
World Affairs
}

NEW FROM CHICAGO

\section{JUSTICE IN THE BALKanS \\ Prosecuting War Crimes \\ in the Hague Tribunal \\ John Hagan}

"This is the first book that really gets inside the workings of the Hague tribunal. Many of the key individuals come alive here, and the reader gets a good sense of the critical role of personal commitments, peculiarities, and ideologies in shaping the work of the court. Hagan makes a very important argument about how individuals and groups can affect the course of human rights enforcement." -Eric D. Weitz, author of $A$ Century of Genocide

\section{Chicago Series in Law amd Society} CLOTh $\$ 29.00$

\section{TOWARD A JUST WORLD}

The Critical Years in the Search for International Justice

\section{Dorothy V. Jones}

"The first half of the twentieth century is widely seen as an era when nationalism and war made a mockery of efforts to strengthen international law and peacefully settle disputes. This new take, in contrast, argues that these decades were pivotal for quietly introducing new ideas about international law into state relations. Jones traces the events, personalities, and institutions that marked the era's efforts to bring reason and rule to the prevention of war." -Foreign Affairs

Cloth $\$ \mathbf{3 0 . 0 0}$

\section{Forthcoming in 2004}

\section{Projections of Power}

Framing News, Public Opinion, and U.S. Foreign Policy

\section{Robert M. Entman}

"There is perhaps no other concept more central to political communication research than 'framing.' Yet as Robert Entman points out, there is no general agreement as to its exact meaning. Projections of Power goes a long way toward rectifying this problem. It is a brilliant book and makes great headway in clarifying the nature of frames." - Steven Livingston, George Washington University

PAPER \$16.00

\section{Kamikaze, Cherry Blossoms, AND NATIONALISMS}

The Militarization of Aesthetics

in Japanese History

\section{Emiko Ohnuki-Tierney}

"In culling history and studying those records left by the young pilots themselves, [OhnukiTierney] arrives at conclusions that offer compelling evidence to conclusions quite opposite those still espoused by the state. To be sure men sacrificed themselves, but for reasons quite different from those often given... . Though her book is a model of academic procedure, it also contains the honest emotion of 'rage against the forces that terminated these brilliant young minds'... . It is this contained, communicated emotion that turns this book from an excellent one into something like a great one." -Donald Richie, Japan Times

Paper \$20.00

The University of Chicago Press

1427 East 6oth Street, Chicago, IL 60637 - www.press.uchicago.edu 


\section{New books from The MIT Press}
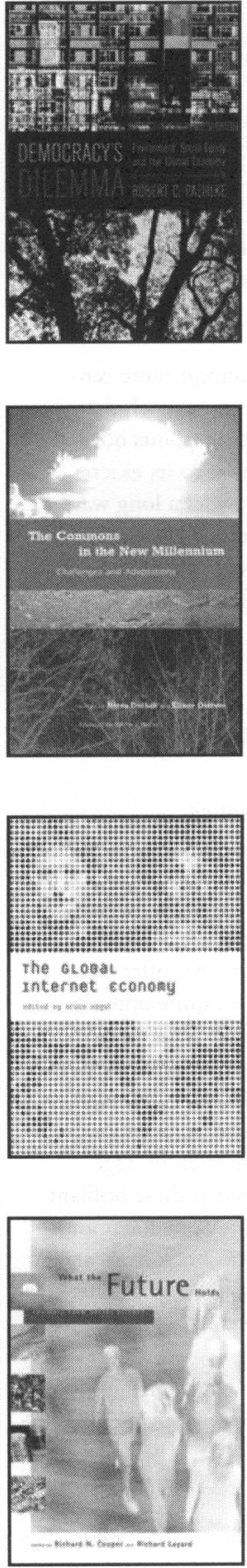

\section{Democracy's Dilemma}

Environment, Social Equity, and the Global Economy

Robert C. Paehlke

"Paehlke makes an ambitious and compelling case ... for a democratic pincer movement from above and below, designed to recapture 'the earth' from 'the globe.' This is an essential contribution from one of our most original and imaginative environmental thinkers." - Andrew Dobson, Open University 304 pp., 1 illus. $\$ 27.95$

\section{The Commons}

\section{in the New Millennium}

\section{Challenges and Adaptation}

edited by Nives Dolšak and Elinor Ostrom

foreword by Bonnie J. McCay

"Enhances our understanding of complex socialecological systems and institutional and organizational resilience, among other topics. Highly recommended!" - Carl Folke, Stockholm University

Politics, Science, and the Environment series 392 pp., 4 illus. $\$ 26.95$ paper

\section{The Global Internet Economy}

edited by Bruce Kogut

"Carefully researched and highly readable, it is essential reading for business leaders, policymakers and academics grappling with the Internet's global reach." - Gerald Faulhaber, The Wharton School, University of Pennsylvania

536 pp., 41 illus. $\$ 39.95$

now in paperback

\section{What the Future Holds}

\section{Insights from Social Science}

edited by Richard N. Cooper and Richard Layard

"The book's lesson is not that prediction is futile, but that it serves a useful purpose by stimulating human responses to avoid possible disasters."

- Foreign Affairs

289 pp. \$15.95 paper 


\section{Capitalism, Not Globalism}

Capital Mobility, Central Bank Independence, and the Political Control of the Economy William Roberts Clark

Clarks's challenge to conventional globalization theories argues that increased financial integration has led to neither widening nor narrowing of partisan differences in macroeconomic policies or outcomes.

\section{The Challenge of Hegemony}

Grand Strategy, Trade, and Domestic Politics

\section{Steven E. Lobell}

An examination of the influence of the international environment on the domestic politics of great powers and the resulting effect on foreign policy.

\section{Carrots, Sticks, and Ethnic Conflict}

Rethinking Development Assistance

Milton J. Esman and Ronald J. Herring, Editors

"A cumulative and devastating critique of the World Bank and IMF's myopic paradigm: its grand abstractions and metrics as applied to growth, development, and the nation state."

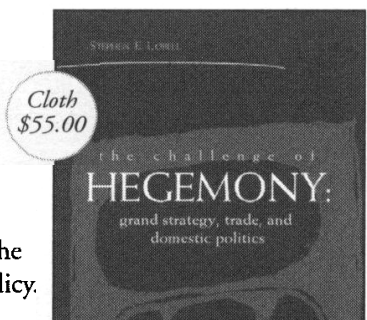

-James C. Scott, Yale University

\section{Protest and the Politics of Blame}

The Russian Response to Unpaid Wages

\section{Debra Javeline}

"When people are not paid wages owed, they generally take some kind of action. In Russia they have not. Why? Debra Javeline's book offers a compelling answer. By focusing on the workers' inability to assign blame, she offers an original explanation that is both grounded in theory and supported with empirical evidence."

-Michael McFaul, Stanford University

\section{Economic Interdependence and International Conflict}

New Perspectives on an Enduring Debate

Edward D. Mansfield and Brian M. Pollins, Editors

A cutting-edge collection of essays on the relationship between economic interdependence and conflict among states, with insight into the question of whether free trade fosters peace. 


\section{A Creative Tension}

The Foreign Policy Roles of the President and Congress

Lee H. Hamilton with Jordan Tama

"This is the best participant/practitioner work on the topic by far. There is a need for it, and the best feature is that it is by a highiy respected participant in the congressionalexecutive relationship, Lee Hamilton."

- James A. Thurber, Director, Center for Congressional and Presidential Studies, American University

Woodrow Wilson Center Press

$\$ 11.95$ paperback

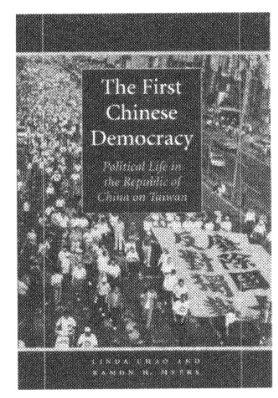

\section{The First} Chinese Democracy

Political Life in the Republic of China on Taiwan

Linda Chao and Ramon H. Myers

"A work of lasting

value that will long stand as the authoritative account of the politics of democracy-

building in Taiwan."-Lucian Pye, Journal of Democracy

$\$ 21.50$ paperback

\section{Cultures of Antimilitarism}

National Security in Germany

and Japan

Thomas U. Berger

"Berger ... does a great service to the scholarly community by showing that cultural theory remains a viable methodology for the study of war."-Douglas A.

Borer Perspectives in

Political Science

$\$ 19.95$ paperback
Constructing Democratic Governance in Latin America

second edition

edited by Jorge I. Domínguez and Michael Shifter

"This comprehensive [book] takes a close look at the status of democratic regimes in Latin America and the Caribbean. .

This is a remarkable collaborative achievement and provides a quick, authoritative, and handy reference that will be invaluable to students. "-Foreign Affairs, reviewing the first edition An Inter-American Dialogue Book $\$ 18.95$ paperback

\section{Crime and Violence in Latin America}

Citizen Security, Democracy, and the State edited by Joseph $\mathrm{S}$. Tulchin and $\mathrm{H}$. Hugo Frühling assisted by Heather Golding

Violence and crime pose serious threats to the relatively fragile democracies of Latin America and the Caribbean. This volume offers timely discussion by attorneys, government officials, policy analysts, and academics from the United States and Latin America of the responses of the state, civil society, and the international community to these threats.

Woodrow Wilson Center Press

$\$ 18.95$ paperback 


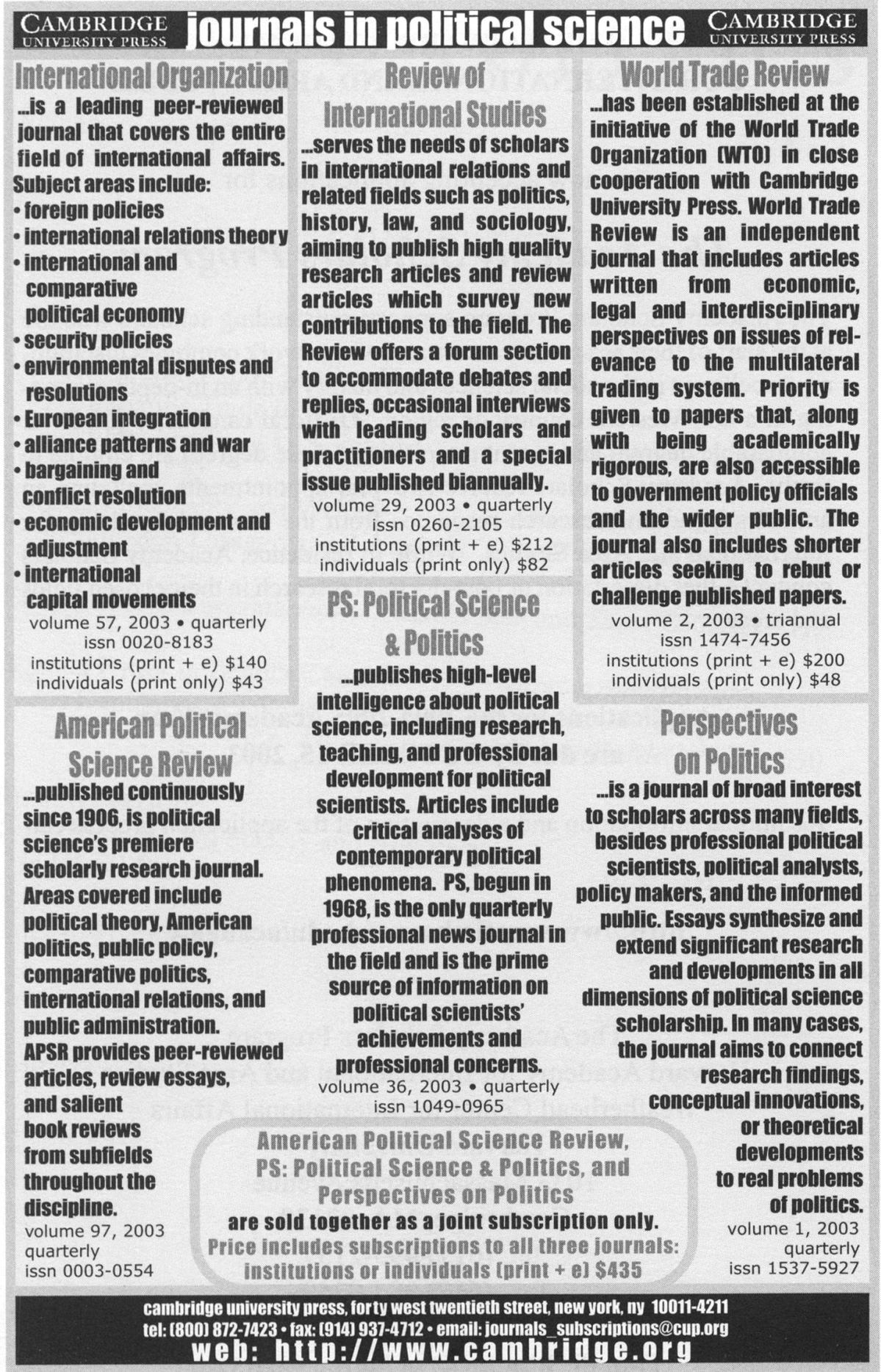




\section{THE HARVARD ACADEMY FOR INTERNATIONAL AND AREA STUDIES}

is now accepting applications for

\section{The Academy Scholars Program}

The Academy Scholars Program supports outstanding scholars who are at the start of their academic careers and whose work combines disciplinary excellence in the social sciences and history with an in-depth grounding in a non-Western country or region. Doctoral candidates (Ph.D. or comparable degree) and recent recipients of these degrees are eligible to apply. Academy Scholars receive two-year appointments, including an annual stipend and research resources from the Harvard Academy for International and Area Studies. While in residence, Academy Scholars conduct either dissertation or post-doctoral research in their chosen fields and areas.

\section{Applications for the 2004-2005 Academic Year are due by OCTOBER 15, 2003}

Additional information and a description of the application process can be found at:

http://www.wcfia.harvard.edu/academy

The Academy Scholars Program

Harvard Academy for International and Area Studies

Weatherhead Center for International Affairs

Harvard University

1033 Massachusetts Avenue

Cambridge, MA 02138

tel: (617) 495-2137

fax: (617) 384-9259 